\title{
Research on Improving Education Governance
}

\author{
Dong Li \\ Xi'an Aeronautical Polytechnic Institute \\ Xi'an, Shaanxi, 710089
}

\begin{abstract}
Educational governance is a process in which multiple subjects jointly manage and educate public affairs. The direct goal of education governance is good governance, that is, "good governance", and the ultimate goal is "good education", which is to establish a new pattern of high efficiency, fair, free and orderly education. Improving education governance system is the key to the promotion of education governance. Its core is to adjust and optimize the relationship between power and responsibility of the main body of the Communist Party through two ways of decentralization and centralization, so as to solve the problems of insufficient social participation in education management, the lack of autonomy in school running, the lack of government's macro management ability, and imperfect internal governance structure of school and so on.
\end{abstract}

Keywords-Educational governance; Governance failure; Governance perspective; Stakeholder

\section{INTRODUCTION}

Governance, refers to implementing all kinds of policies and regulations and monitor the implementations of these policies to balance the power of all the members within an organisation or a society. In terms of education governance, it refers to the implementation of system and all kinds of policies and regulations which are related with education. The aim of education governance is to reach to the good education in community. Based on the understanding of the importance of education governance, this essay attempts to explore the purpose of education governance from four basic aspects, in what ways can educational governance be planned and actioned. The relationship between education governance and government, the problem of education governance, and the governance failure.

\section{PlANNING AND ACTION OF EDUCATION GOVERNANCE}

Based on the argument of Beavis governance, leadership and management are three different aspects which form an overall and complicated process of administration [1]. The statement by Beavis represents the relationship between different sectors and powers in society related with education. What is more, Beavis viewed governance as the cooperative forces between government, leadership and management and the process of educational governance aims to deliver the institutional values and perspectives in order to reach to the consistency and effective leadership and management. Management brings the high level of predictability and consistency in the process of governance. It requires leaders and individuals to apply the effective planning and actions in the process in order to reach to the objectives in educational governance. But according to Beavis, the leadership is about how to cope with movement and change. The most important aspect of leadership can be described as establishing direction, inspiring and assigning works to people to that direction. Similarly, Carver and Carver argued that governance is about the values and approaches in policy which provide the all related responsibility to reach to objectives [2].

But in what ways can the governance be executed, planned and actioned? In other words, in what ways can the objectives of governance be realised through a series of actions and plans. From a wide perspective, the action of governance should be implemented by people. But in the process of governance, people should still be involved in self-surveillance and selfregulation. Rose et al., pointed out that technologies such as audits, standards and budgets are able to operatinalize the programs of governance which are characterised by the forms of new public management [3]. To be specific, many scholars have introduced the term of decentralisation which refers to the devolution among different nations and different forces in community [4].They argued that the democratic devolution, functional decentralisation and the fiscal decentralisation are critical to reach to the objectives of good governance.

From the above analysis, it could be concluded that in order to make sure that good governance could be implemented and actioned effectively, it needs the decentralisation of government and the cooperation among different sectors in community. Such cooperation and decentralisation, are found to be extremely important for the improvement of educational governance in Chinese context.

\section{RELATIONSHIP WITH THE GOVERNMENT}

Based on the above analysis on the definite and nature of governance, it can be found that the mechanism, practice of governance cannot leave the participation of government, which plays a critical role in the process of governance. But what is the exact relationship between education governance and government? According to Volanskye and Friedman, the global educational system tended to be more centrally managed since the late 19 th century to the early 20th centuries. It was because most of countries began to adopt the police of education for all to encourage children to take part in primary and elementary schools. However, the economic crisis in late 1970s and early 1980s reflects the result of expansion of education system in these countries. It reflected people's dissatisfaction towards the ability of government to supervise and control education governance. While the public sector reforms which is known as New Public Management (NPM), 
has transformed the role of government and public services in many countries. The reform in public service is the response to the enlarging expansion and increasing cost on government [5]. Since that time, people paid more attention on education governance and they had realised that educational practice should be oriented by market in order to maximise the effectiveness and efficiency of education. Such policy discourse reflects the people's concern on approaches of education rather than the ends of education. The New Public Management believes that educational governance has shown a convergence to the educational policy discourse which advocates the wide cooperation between different sectors and forces such as international organisations and government. Both north and south countries in global range perform the similar tendency [6]. It could be found that the transformation from government to governance is the shift from the value that believes government is the only source of policy authority to the belief that relies not only on government but on different authorities and forces in the global range. It seeks more the production of self-regulating individuals which plays a greater responsibility in related with markets. It views education as the economic factor and it advocates to measure economic factor through the quantity and quality perspectives. Such measurement, according to Rizvi and Lingard, can be considered as the competitive aspect for national economy. Such transformation from government to governance reflects the growing importance of international assessment progress such as the Program for International Student Assessment (PISA) which was established in the late 1990s.

In summary, the relationship of government in past years' educational governance practice can be concluded as the trend of decentralised management, the focus more on efficiency and effectiveness and the involvement of other organisations as the providers of pubic services.

\section{What IS THE PROBLEM REPRESENTED TO BE?}

It should be critically illustrated that how we think about the educative purpose of governance determines how we should participate in the process of governance. But in the process of participating into education governance, which problem should be represented to be? And which problems are important to be understood? According to Bacchi, public policies provide shape to problems. It is important to understand and analyse the problems from the perspective of target of public policy [7]. The methodology provided by Carol Bacci offers a perspective to have a close look at the problems represented to be in the governance. This model provides the following problems. Firstly, how do we devolve responsibility for self-rule within he limitations. Secondly, how do we make sure that the results designed by owners are achieved and thirdly, how do we control events to limit the unexpected and unplanned issues. All these problems, according to Bacchi, are about how people are to think about what they are doing in governance. In fact, many countries and regions have introduced all kinds of measurements and approaches to exemplify the solutions to these problems. For example, Australia has developed the standards to require teachers and schools to obey the certain ways of making sure that their teaching approaches and behaviours in class are in consistency with rules and regulations. In terms of the educational governance situation in China, there are still few schools and educational institutions have the standards and measurement to exemplify in what ways should teachers are governed in the domestic context. From the above analysis, it could be concluded that the policies in educational governance should be based on the consensus towards the problems represented to be in the process of governance. And the standard measurement and assessment system should be established to make sure that the educational governance could be implemented effectively across the country.

\section{GOVERnANCE FAILURE}

The Enron scandal is an example of governance failure in history. Enron was established in 1985 and in a short time, it has become one of the most successful and innovative company as the energy trader and supplier. The regulatory environment at that time al-lowed the company to flourish but it began to crumble under its own weight by the fall of 2000 , when the CEO of the company had a way of hiding finical losses of the trading business and other operations of company. Enron's executives were taking use of a series of accountancy loopholes and complicated financial deals to deep debt off the balance sheet. Sonnenfeld pointed out that many traditional understandings of good governance cannot guarantee the real good governance. He argued that elements related with humans are extremely important in the process of governance [8].

In order to understand what governance failure is, it should firstly understand what good governance is. For a long historical time, governance has been closely related with good governance in discourse. It was often associated with market orientations. But until the 1980s, good governance has not entered into the discussion of pubic theories and policy making. In the 1989, the World Bank started to use the term good governance and crisis of governance to describe the situations in most developing counties. The Untied Nations publicised the eight characteristics of good governance, which are transparency, accountability, rule of law, effectiveness and efficiency, responsiveness, equity and consensus oriented and participatory[9]. Compare with good governance, the other side of governance could be considered as the failure of governance. For example, implementing the policies without effective rules and laws, the irresponsible behaviours and inequity in the process of governance could be viewed as the forms of failure. The inability in perform collectively binding decisions effectively designed and implemented is the representative of failure governance. How-ever, the ability to overcome such failure in governance requires strong ability to mobilise the political resources to involve with both internal and external forces and sabotage their formation and implementation [10].

In summary, understanding the concept of good governance is critical to comprehend the failure in governance. According to the above analysis, it could be found that governance failure is the condition of ungovernability. It fails to come to a cooperative solution to all kinds of conflicts.

The above four chapters help to underpin the most important facts of governance, the implementation, the failure, the problem and the relationship with government. It could be 
concluded that modern governance is based on the transformation from government-controlled system to market oriented system which values market effectiveness and efficiency, equity and cooperation. Understanding the failure of governance is based on the comprehension about the nature and meaning of good governance, the representatives of problems and the relationship with government. Establishing the cooperative relationship among different forces and maintaining the effective implementation and assessment system within the educational system are considered to be representatives of good governance.

\section{COMBINING Key PoINTS OF The EIGHT TOPIC QUESTIONS}

This module provides the good opportunity for me to have an in-depth understanding about the education governance. Education governance is a complex process and behaviour which needs the cooperation of different sectors and individuals such as students, teachers, schools, government and society. Understanding the aim and objectives of education governance is considered to be critical to develop the social welfare. Based on the understanding of the importance of education governance, this essay attempts to explore the purpose of education governance from eight basic aspects, the meaning of education governance, the educative purpose of governance, the worldview of education governance, the participants of education governance, in what ways can educational governance be planned and actioned, the governance failure, the problems of governance and the relationship with government. The eight problems in educational governance imply the most important issues within the implementation of public policy and public service. From the above analysis, it could be found that it needs to look beyond the effectiveness and efficiency to how the governance should be implemented, it should have a more broad perspective from a bigger picture to examine how the public interest and welfare should be delivered and served. Being able to govern refers to owning the ability to collectively correlating different forces and decisions together to improve the delivery of public service. And the good governance should be protected and promoted through all kinds of forces and powers in community.

From my personal experience in school attendance, I found that most schools and universities in past paid less attention on governance. Most of them had no idea of the importance of participation, consultation and communication of different individuals and powers within the institution. Education in schools, never should refer to the single process of delivering knowledge and value, it refers more to the cooperation and interactive process among different individuals and organisations. However, in current domestic education system in China, there is less practice in education governance which enables the schools and universities to provide all kinds of consulting and participative services to develop students' potentials. Especially, the complicated relationship between different sectors within the education system, as well as the complicated relationship between schools and social organisations pose a difficult circumstance to reach to the good governance in education system.

\section{CONCLUSION}

In conclusion, the above analysis provides the in-depth discussion towards the issue of educational governance. The term of governance, refers more to the general agreement on the common values and principals upon which it should bring about the benefits to each individual in the society. Through analysing the eight problems in the issue, it came to the conclusion that good governance not only lies in the effective and efficient implementation and the market orientation, but also lies in the cooperation and standards measurements among different sectors, forces and shareholders in society. These experience and lessons should be borrowed by China to improve the current situation of educational governance in order to reach to the objective of good governance in education field.

\section{REFERENCES}

[1] Beavis A. K,Governance, leadership and management: an eternal problematic braid. Leading and Managing,1997, 3(4), 288-300.

[2] Carver, J., \& Carver, MA carver policy governance guide, set: the carver policy governance guide series on board leadership, revised and updated. Community De-velopment, 2011,42(1), 131-132.

[3] Rogers B. Education governance EDUC 9617 Topic Study Guide. Adelaide Flin-ders University, 2017.

[4] Caldwell, C., \& Karri, R.,Organizational governance and ethical systems a cove-nantal approach to building trust. Journal of Business Ethics, 2005,58(1-3), 249-259.

[5] Rizvi, F., \& Lingard, B. Globalizing education policy. Globalizing Education Policy,2010.

[6] Bacchi C,Analysing policy: what is the problem represented to be? Frenchs Forest NSW: Pearson Australia, 2009.

[7] Sonnenfeld, D. A., \& Mol, A. P. J, Globalization, governance and the environ-ment. Thousand Oaks Sage,,2002,

[8] UN ESCAP,Good Governance .Retrieved 7th February,2014,from http://www.unescap.org/pdd/prs/ProjectActivities/Ongoing/gg/governan ce.asp.

[9] Offe C,Ungovernability. In A. Azmanova \& M. Mihai(Eds), Reclaiming democ-racy : judgement, responsibility, and the right to policies(77-86). New York : NY. Abingdon Oxon: Routledge, 2015.

[10] Sellar, S, A feel for numbers: affect, data and education policy. Critical Studies in Education, 2015, 56(1), 131-146. 